\title{
Government expenditure on human capital and growth in Namibia: a time series analysis
}

Christopher P. P. Shafuda ${ }^{1,2^{*}}$ and Utpal Kumar De ${ }^{2}$

\section{*Correspondence:}

poshafuda@gmail.com;

cshafuda@unam.na

${ }^{1}$ Department of Economics

and Managemen, University

of Namibia Rundu, 44001,

Kavango East, Rundu,

Namibia

Full list of author information

is available at the end of the

article

\begin{abstract}
An attempt is made in this paper to examine the impacts of government spending on human capital on human development indicators like healthcare outcomes, education achievements and increase in national income in Namibia using time series data from 1980 to 2015. The analysis reveals a significant long-run inverse relationship of government spending on healthcare with fertility rate, infant mortality rate and under-5 mortality rate. However, no co-integration is observed between government spending on healthcare and life-expectancy or adult mortality rate. Also, the findings reveal a significant long-run positive relationship of government spending on education with literacy rate, net primary and gross tertiary enrolment rate. Whereas, no co-integration between government spending on education and gross enrolment rate at primary and secondary level is observed. The vector auto-regression analysis revealed significant impacts of expenditure on healthcare and education on the GDP growth in the long run through improved human resources. The results are thus in favour of continuation of expansionary government expenditure policy to achieve faster economic growth in Namibia. However, drastic changes should be adopted to improve basic education and primary healthcare in the country.
\end{abstract}

Keywords: Fiscal policy, Human capital, Healthcare and education expenditure, Development, Co-integration, Error correction model, Namibia

JEL Classification: E62, H11, H41, H71, H75 C13, I18, I28

\section{Introduction}

Recent studies on economic growth and development suggest that accumulation of human capital plays an important role in enhancing economic growth as well as human development (Suri et al. 2011). The concept of human capital can be understood as a set of intangible resources needed in the labour factor to improve productivity (Goldin 2016). These are associated with knowledge and skills acquired through education, experience and healthcare (Schultz 1961; Becker 1962). Thus, Benos and Zotou (2014) defined human capital as the set of knowledge, skills, competencies and abilities embodied in individuals and acquired, through education, new learning, training, medical care and experience. Perhaps because new learning and training cannot be measured easily, health and education status has been the more commonly used human capital measures in literature on the relationship between human capital and economic growth (Ogundari and

(c) The Author(s) 2020. This article is licensed under a Creative Commons Attribution 4.0 International License, which permits use, sharing, adaptation, distribution and reproduction in any medium or format, as long as you give appropriate credit to the original author(s) and the source, provide a link to the Creative Commons licence, and indicate if changes were made. The images or other third party material in this article are included in the article's Creative Commons licence, unless indicated otherwise in a credit line to the material. If material is not included in the article's Creative Commons licence and your intended use is not permitted by statutory regulation or exceeds the permitted use, you will need to obtain permission directly from the copyright holder. To view a copy of this licence, visit http://creativeco mmons.org/licenses/by/4.0/. 
Awokuse 2018). Thus, education and health are considered as the most significant human capital investments. These two play a pivotal role in the process of economic growth.

The idea of education and health as a form of human capital has emerged in the works of Schultz (1961), Denison (1962), Mushkin (1962) and Becker (1962, 1964a) which highlighted the role of education and health in human capital formation. The findings were that human capital contributed to the enhanced productivity of labour force, which later leads to growth of national income. According to the recent literature, education and good health have certain spill-over benefits other than improving productivity of labour and benefiting the individuals who receive it; in modern economies, human capital is a key determinant of economic growth. Thus, fiscal policy helps economic growth if human capital is formed in the process of infrastructure development necessary for schooling, skill development and enhancing good health of the citizens (Agenor 2008; Mekdad Dahmani and Louaj 2014).

Education is considered as a long-term investment that leads to rise in productivity in future. Thus, education has positive long-run and short-run effect on economic growth (Afzal et al. 2010; Lin 2003; Tamang 2011). Baldacci et al. (2004) using data from 120 developing countries for the period 1975-2000 found long-run positive relationships between educational expenses and economic growth. Hence, studies have shown significant improvement in school attainment across the developing world in recent decades (Hanushek 2013). Despite admitting positive impact of education on economic growth, Gray et al. (2007) argued that more public spending on education and healthcare are not always associated with better educational and health outcomes. Gray (2007), however, found a positive correlation between per capita income and learning outcomes in some countries like Korea, Poland, and Romania, where better educational outcomes are associated with their levels of per capita income.

Grossman (1972) developed a model in which illness prevents work so that the cost of ill health causes loss of labour time, and therefore, low productivity. So, health has been recognised as one of the fundamental elements of human capital (Bloom et al. 2001; Barro 2013). Strauss and Thomas (1998) stated that health and income mutually affect each other. Healthy communities tend to enhance physical abilities and mental clarity, which in turn increase productivity (Bloom and Canning 2000). Thus, problems affecting health cause negative shocks in growth. Whilst adequate education and good health spur a more productive labour force that could stimulate growth (Bloom et al. 2004). Ogundari and Abdulai (2014) also show that a better educated and healthier society is likely to create and adapt new technologies and consequently increase growth.

Studies have also shown that health can affect growth indirectly through other variables like education, mobility and therefore skill development (Bloom and Canning, 2000; Hanushek 2013). Health status can affect educational performance as well as people's ability to move from place to place to acquire specific training and skill. Thus, good health can be associated with increased levels of schooling and high education performance. Schooling affects ones' ability to access the labour market. Thus, the role of improved schooling has been a central part of the development strategies of most of the countries and of international organizations.

The idea of treating education and health spending as an investment decision is highlighted in the works of Becker (1962, 1964b), Bowles (1967) and Mincer (1984). Evidence is also there which reveals that the social rate of return decreases over level of education. 
McMahon (1997) and Green et al. (1999) suggest that investment in basic rather than higher education is a more effective strategy for skill development and eventually economic growth. Spending on education and healthcare helps promoting efficiency, knowledge and inventions, all of which contribute to the economic growth and development of a nation (Maitra and Mukhopadhyay 2012). Sen (1999) also strongly argued in support of development approach that ensures high investments in education, health and social infrastructure to accelerate growth. On the other hand, Barro (1996) found an incentive to invest in education given an increase in health indicators.

Most of the studies reveal a positive impact of educational and healthcare spending by the government on social indicators (Gupta et al. 2002; Commander et al. 1997). Although a number of empirical studies found a positive relationship between healthcare and educational spending on economic growth, a few studies reveal mixed results like bidirectional or negative relationship across developing countries (Wilson 1995; Wang 2011).

The Namibian healthcare and education system were designed in line with apartheid mode in the pre-independence period. Instead of providing necessary human resource base to promote equitable social and economic development across all races and ethnic groups, previously disadvantaged groups were left out. Hence, a switch in policy with emphasis on primary healthcare and basic education system was adopted. Healthcare and education were reformed to provide effective, equitable and quality health and education services to all Namibians irrespective of the colour of their skin or the tribe and religion they belong to. As a result, Namibia became one of the highest spenders on education and healthcare amongst all the developing countries (Zaaruka Biwa and Kalenga 2001; Lowet al. 2003). According to UNICEF (2017), Namibia has the third highest public education expenditure to total government spending and seventh highest education expenditure to GDP ratio amongst 115 developing countries.

Kalimbo (2015) on the policy briefing report on Namibia competitiveness ranking stated that healthcare and education system remain weak in Namibia. Isaksson (2007) provided a comprehensive review on the determinants of total factor productivity with particular emphasis on the Namibian context. However, quality of the labour is determined by educational attainment and on the quality of the healthcare system. Poor quality of labour impacts productivity negatively as it has caused skill mismatch in the labour marked. The IMF (2014) notes that skills mismatch in the Namibian labour market have contributed to the persistently high level of structural unemployment. However, no substantial analysis has been made on the impact of government expenditure on healthcare and education on the related outcome and GDP growth in Namibia so far that would help in further policy formulation.

The present paper thus tries to (1) analyse if government spending on healthcare and education has a long-term impact on health outcomes (mortality rate and life expectance) and on level of education outcomes (literacy rate and school enrolment rate) in the country and finally (2) to find out whether a long-run relationship exists between government spending on healthcare and education both and GDP in Namibia.

\section{Materials and methods}

Time series data on variables of interest like total government expenditure, expenditure on education and Healthcare, government transfer of fund for social welfare, per capita GDP (in Namibian dollar), health indicators (fertility, mortality, life expectancy) 
and education indicators (literacy rate, enrolment at various level) are obtained from the World Bank and ministries of health, education and finance, Government of Namibia for the period 1980-2015, are used for the analysis. The choice of starting and ending period was constrained by the availability of data.

It is known that trended time series may potentially create spurious regression results. One way of resolving this is to difference the series successively until stationarity is achieved and then use the stationary series for regression analysis. According to Asteriou and Hall (2011), this solution, however, is not ideal because it not only differentiates the error process in the regression, but also no longer gives a unique long-run solution. Thus, Augmented Dickey-Fuller (ADF) unit root test and Vector Auto Regressive (VAR) as well as co-integration have been employed in the analysis. Depending on the co-integrated relation amongst the variables, error-correction model (ECM) is used to analyse the relationship between government spending on healthcare and education and GDP or per capita GDP as an indicator of economic growth (Liu et al. 2008; Wahab 2004; Vamvoukas and Loizides 2005).

Testing of stationarity of the original variables is done using ADF unit root test (Dickey and Fuller 1979) and then test of co-integration between the variables is done by Johansen's test (Johansen 1988). For ADF test the following equation is estimated.

$$
\Delta \operatorname{Ln} X_{t}=a+b \operatorname{Ln} X_{t-1}+\sum c_{j} \Delta \operatorname{Ln} X_{t-j}+e_{t}
$$

where $X_{t}$ denotes the respective variables of interest. $\Delta$ is the difference operator, whilst $a$, $b$ and $c$ are parameters to be estimated. If the calculated ADF statistic is less than (higher than in absolute term) the critical value, then the null hypothesis $\left(\mathrm{H}_{0}\right)$ of unit root is rejected and the series is considered to be stationary or integrated of order zero, i.e. $I(0)$.

According to Sim (1980), if there is simultaneity amongst variables, Vector Autoregressive (VAR) model should be employed. A VAR model suggests that if there is no much knowledge about the forces influencing a variable, then treat those variables symmetrically. This is shown by the following system of equations:

$$
\begin{aligned}
& \operatorname{Ln} Y_{t}=\beta_{10}+\beta_{11} \operatorname{Ln} Y_{t-1}+\beta_{12} \operatorname{Ln} X_{t-1}+U_{\text {Lnyt }} \\
& \operatorname{Ln} X_{t}=\beta_{20}+\beta_{21} \operatorname{Ln} Y_{t-1}+\beta_{22} \operatorname{Ln} X_{t-1}+U_{\text {Lnxt }}
\end{aligned}
$$

where $U_{\mathrm{yt}}$ and $U_{\mathrm{xt}}$ are correlated white noise and $\beta_{i j}$ are coefficients. Equations (2) and (3) are in reduced form. $Y_{t}$ and $X_{t}$ are the variables to be tested for their short-run relationship, whilst $Y_{t-1}$ and $X_{t-1}$ are lagged values of $Y_{t}$ and $X_{t}$, and $t=1,2,3 \ldots, T$ (19802015). $\beta_{\mathrm{s}}$ are the parameters to be estimated.

\subsection{Johansen co-integration test and error-correction model}

The concept of co-integration was first introduced by Granger $(1980,1981)$ and elaborated further by Engle and Granger (1987), Engle and Yoo (1987), Phillips and Ouliaris (1990), Stock and Watson (1988), Phillips $(1986,1987)$ and Johansen $(1988,1991)$. Testing for co-integration is a necessary step to check if there is an empirically meaningful long-run relationship between the variables. If variables are not co-integrated, it implies that there is no valid base for inference based on standard distributions. 
If $Y_{t}$ and $X_{t}$ are co-integrated, meaning $\hat{u}_{t} \sim I(0)$ where $\hat{u}$ denotes the residuals. Thus, we can express the relationship between $Y_{t}$ (outcome variables say mortality, fertility, literacy, enrolment, etc.) and $X_{t}$ (government expenditure on healthcare or education) with an Error-Correction Model (ECM) specification as

$$
\Delta \operatorname{Ln} Y_{t}=a_{0}+b_{1} \Delta \operatorname{Ln} X_{t-1}-\pi \hat{u}_{t}+e_{t} .
$$

ECM enables us to include both the short- and long-run information. In this model, $b_{1}$ is a multiplier impact, short-term adjustment effect, that measures the immediate impact a change in $X_{t}$ has on a change in $Y_{t}$, whilst $\pi$ is the feedback effect, or the adjustment effect. It shows how much of the disequilibrium is being corrected in each time.

In the error-correction model, relevant error-correction terms $\left(\mathrm{EC}_{t-1}\right)$ are included in the standard Granger causality procedure after all variables have been made stationary by differencing, which yields Eqs. 5 and 6 .

$$
\begin{aligned}
& \Delta \operatorname{Ln} Y_{t}=\alpha_{1}+\sum_{i=1}^{n} \beta_{i} \Delta \operatorname{Ln} Y_{t-i}+\sum_{j=1}^{m} \gamma_{j} \Delta \operatorname{Ln} X_{t-j}-\emptyset_{1} \mathrm{EC}_{t-i}+\varepsilon_{1 t} \\
& \Delta \operatorname{Ln} X_{t}=\alpha_{2}+\sum_{i=1}^{n} \sigma_{i} \Delta \operatorname{Ln} X_{t-i}+\sum_{j=1}^{m} \partial_{j} \Delta \operatorname{Ln} Y_{t-j}-\emptyset_{2} \mathrm{EC}_{t-i}+\varepsilon_{2 t}
\end{aligned}
$$

where $\Delta$ is first difference operator, $t$ is time, $\sigma_{i}, \beta_{i}, \gamma_{i}, \sigma_{i}$, and $\delta_{i}$ are coefficients associated with VAR, the subscripts denote the order of that equation. $R_{t}=\left(\varepsilon_{1 t}, \varepsilon_{2 t}\right)^{\prime}$ is a vector of uncorrelated disturbances, whilst $\alpha_{1}$ and $\alpha_{2}$ are constants. $\mathrm{EC}_{t-1}$ is the error-correction term. The independent variables are said to cause the dependent variable if the error-correction term $\left(E C_{t-1}\right)$ is significant $\left(\varnothing_{1}\right.$ or $\varnothing_{2}$ is nonzero) or the coefficients of the lagged independent variables (summation of $\gamma_{j}$ or summation of $\partial_{j}$ is significant). However, if the series are not cointegrated, Granger test is carried out without the error-correction terms.

\section{Empirical results and discussion}

Table 1 shows the results of ADF test of stationarity for the log-transformed variables at level, first difference and second difference form. The results failed to reject the null hypothesis of non-stationarity (Unit Root) at level form including intercept, for all variables.

Public expenditure on healthcare, infant mortality and under-5 mortality is found to be integrated of order 1 , whilst life expectance and adult mortality rate (male and female) are found to be integrated of order 2 . Therefore, variables that are integrated of order 2 can be safely assumed to be non-co-integrated other variables that are integrated of order 1 . Table 1 reveals that the hypothesis of non-stationarity is rejected at first difference level for variables like education expenditure, adult, elderly and youth literacy, primary and secondary net enrolment as well as secondary and tertiary gross enrolment. Thus, those variables are integrated of order 1 , that is $I(1)$. Only the primary enrolment rate is stationary at second difference. Per capita education, healthcare, overall expenditure and per capita GDP are integrated of order 1. As majority of the variables are integrated of same order (1), we further examined their co-integrating relationship using Johansen co-integration test. 
Table 1 Test of stationarity of health and education expenditures and health output

\begin{tabular}{|c|c|c|c|c|}
\hline Variable & $\begin{array}{l}\text { Level } \\
\tau\end{array}$ & $\begin{array}{l}\text { 1st Diff. } \\
\tau\end{array}$ & $\begin{array}{l}\text { 2nd Diff. } \\
\tau\end{array}$ & Remark \\
\hline Health expenditure & -1.211 & -3.255 & & I(1) \\
\hline Education expenditure & -0.213 & -6.629 & & I(1) \\
\hline Life expectancy at birth & -1.416 & -0.462 & -4.042 & I (2) \\
\hline Female mortality rate & -2.4934 & -1.634 & -5.499 & I (2) \\
\hline Male mortality rate & -2.5266 & -1.5237 & -5.518 & I (2) \\
\hline Infant mortality rate & 0.585 & -6.863 & & I(1) \\
\hline Under-5 mortality rate & 0.830 & -5.036 & & I(1) \\
\hline Fertility rate & 2.946 & -3.393 & & I(1) \\
\hline Adult literacy rate & -1.433 & -3.266 & & I(1) \\
\hline Elderly literacy rate & -0.3441 & -4.402 & & I(1) \\
\hline Youth literacy rate & -0.9857 & -3.4127 & & I(1) \\
\hline Primary enrolment rate (G) & -1.273 & -1.6022 & -7.425 & I(2) \\
\hline Secondary enrolment rate $(\mathrm{G})$ & -1.617 & -3.521 & & I(1) \\
\hline Tertiary enrolment rate (G) & -0.693 & -4.927 & & I(1) \\
\hline Primary enrolment rate $(\mathrm{N})$ & -2.867 & -6.172 & & I(1) \\
\hline Secondary enrolment rate $(\mathrm{N})$ & -2.182 & -3.876 & & I(1) \\
\hline P/C edu. expenditure & -0.214 & -6.628 & & I(1) \\
\hline $\mathrm{P} / \mathrm{C}$ health expenditure & -1.213 & -3.249 & & I(1) \\
\hline $\mathrm{P} / \mathrm{C}$ total expenditure & 0.5397 & -7.324 & & I(1) \\
\hline P/C GDP & 1.7274 & -3.530 & & I(1) \\
\hline \multirow[t]{2}{*}{ Critical value at } & $1 \%=-3.689$ & $1 \%=-3.639$ & $1 \%=-3.646$ & \\
\hline & $5 \%=-2.971$ & $5 \%=-2.951$ & $5 \%=-2.954$ & \\
\hline
\end{tabular}

\subsection{Tests for co-integration}

As mentioned earlier, the Johansen Co-integration test is used to measure the existence of long-run relationship between the variables. But Johansen co-integration approach is sensitive to the lag length. So, the lag length is determined in a systematic manner. There are different criteria for determining the lag length selection. One of the criteria is using Akaike information criterion (AIC). According to the AIC standard, we have to choose the model with the lowest AIC value. The lower the value of AIC, the better is the model. Mathematically, an $\mathrm{AR}(\mathrm{p})$ process of a series may be represented by

$$
y_{t}=\alpha_{1} y_{t-1}+\alpha_{2} y_{t-2}+\cdots+\alpha_{n} y_{t-n}+\varepsilon_{t}
$$

where $\alpha_{1}, \alpha_{2}, \ldots \alpha_{n}$ are autoregressive parameters and $\varepsilon_{t}$ are normally distributed random error terms with a zero mean and a finite variance $\sigma^{2}$.

The estimation of $\operatorname{AR}(p)$ process involves two stages: First, the AR lag length $p$ is identified based on certain criteria. Second, the numerical values for intercept and parameters are estimated using regression analysis. The autoregressive parameters are independently generated from uniform distribution with values ranging from -1 to 1 exclusively. Measures are taken to ensure that the sum of these simulated autoregressive parameters is less than unity in magnitude $\left(\left|\alpha_{1+} \alpha_{2+} \alpha_{3+} \alpha_{4}\right|<1\right)$ so as to avoid nonstationary AR process.

The Akaike information criterion is given by 


$$
\operatorname{AIC}_{p}=-2 T\left[\ln \left(\hat{\sigma} p^{2}\right)\right]+2 p
$$

where $\hat{\sigma}_{p}^{2}=(T-p-1)^{-1} \sum_{t=p}^{T} \hat{\varepsilon}_{t}^{2}$; $\varepsilon_{t}$ is the model's residuals and $T$ is the sample size and the cap sign $\left({ }^{\wedge}\right)$ indicates its estimated value (see Liew 2000; Brockwell and Davis 1996).

The series optimum lags length ranged from 4 to 8 for healthcare expenditure and health output variables (Table 2). Furthermore, the series optimum lags length for cointegration between education expenditure and education output variables ranged from 1 to 5 whilst the series optimum lag length for co-integration between per capita GDP and government expenditure on education, as well as per capita GDP and government expenditure on health care all have 1.

The trace statistic and Max-eigen value test both indicate 1 co-integrating equation between healthcare expenditure and fertility rate at the 0.05 level of significance (Table 3). The results also reveal that as per both Trace statistic and Max-eigen value tests, there is one co-integrating equation between healthcare expenditure and infant mortality rate. Also, there is one co-integrating relation between Healthcare Expenditure and Under-5 Mortality as per both the Trace statistic and Max-eigen value tests. The co-integration result therefore reveals that government expenditure on healthcare has a long-run impact on fertility rate, infant mortality rate and Under-5 Mortality.

\subsection{Co-integration between education expenditure and education output variables}

Both trace statistic and Max-eigen value tests indicate the existence of maximum two co-integrating equations at the 0.05 level between education expenditure and adult literacy rate. Also, one co-integrating relation exists between education expenditure and elderly literacy rate as well as between education expenditure and youth literacy rate. This means that an expansionary fiscal policy through expanding government expenditure on education has a long-run impact on the literacy rate at all levels (youth, adult and elderly). Though the test reveals two co-integrating relations of education expenditure

Table 2 Optimal lag selection for co-integration analysis

\begin{tabular}{lc}
\hline Series name & Lowest \\
\hline Health expenditure and healthcare output variables & \\
LNHealth_Exp and LNFert_Rate & 4 \\
LNHealth_Exp and LNInf_Mort_Rate & 6 \\
LNHealth_Exp and LNUnder5_Mort_Rate & 8 \\
Education expenditure and education output variables & 2 \\
LNEdu_Exp and LNAdult_Lit_Rate & 3 \\
LNEdu_Exp and LNEIderly t_Lit_Rate & 5 \\
LNEdu_Exp and LNYouth_Lit_Rate & 1 \\
LNEdu_Exp and LNPrimary_Net_Enrol & 3 \\
LNEdu_Exp and LNSec_Gross_Enrol & 1 \\
LNEdu_Exp and LNSec_Net_Enrol & 4 \\
LNEdu_Exp and LNTertiary_Gross_Enrol & \\
Per capita GDP, education and health expenditure & 1 \\
LN_PC_GDP LN_PC_EDU_EXP & 1 \\
LN_PC_GDP LN_PC_HEALTH_EXP & \\
\hline
\end{tabular}


Table 3 Results of co-integration test between healthcare expenditure and health outputs

\begin{tabular}{lrr}
\hline Null hypothesis & \multicolumn{1}{c}{$J_{\text {trace }}$} & $J_{\max }$ \\
\hline $\begin{array}{l}\text { Health expenditure and fertility rate } \\
r=0\end{array}$ & $17.612(0.023)$ & $17.227(0.017)$ \\
$r=1$ & $0.384(0.535)$ & $0.384(0.535)$ \\
Health expenditure and infant mortality rate & & \\
$r=0$ & $26.278(0.001)$ & $24.207(0.001)$ \\
$r=1$ & $2.071(0.150)$ & $2.071(0.150)$ \\
Health expenditure and under-5 mortality rate & & $18.622(0.009)$ \\
$r=0$ & $18.853(0.015)$ & $0.231(0.631)$ \\
$r=1$ & $0.231(0.631)$ &
\end{tabular}

with primary net enrolment rate and one equation with tertiary gross enrolment rate, there is no co-integrating relation between education expenditure and gross as well as net secondary enrolment ratio (Table 4). It implies that government expenditure on education has a long-run influence on net primary emolument and tertiary enrolment rate. Expansionary fiscal policy through increasing government expenditure on education has no influence on secondary enrolment rate.

\subsection{Cointegration of per capita GDP and per capita education with healthcare expenditure} Both the trace statistic and Max-eigen value tests indicate the presence of one co-integrating equation between per capita GDP and education expenditure at 0.05 level of significance (Table 5). Similar result is revealed between per capita GDP and per capita healthcare expenditure.

\subsection{The long-run relationship and vector error-correction model}

Since there is co-integration between the major health/education output variables and expenditure on healthcare/education, vector error-correction model is estimated to examine the short-run adjustment of the dependent (target) variable/s and the impacts of various explanatory variables on it. The normalised long-run co-integrating equation between government expenditure on healthcare and education and fertility rate, mortality rate, literacy rate and enrolment rate as well as per capita GDP and per capita healthcare and education expenditure is formally presented in Box 1. To safeguard the reliability of results, we limit the number of variables in a single VAR to maximum four most relevant variables only.

From the results (Box 1), coefficients of government expenditure on healthcare and per capita GDP are negative and statistically significant in Eqs. 9 and 10. Hence, the long-run impact of government spending on healthcare and per capita GDP on fertility rate, as well as with infant mortality rates, is found to be significantly negative in the co-integrating vector. The coefficients of literacy rate are found to be not significant. This implies that rate of literacy has no long-run significant impact on fertility rate and infant mortality rate.

The results in Eqs. 11-15 reveal that there is a positive and significant long-run relationship between government spending on education and educational development measures (literacy rate and enrolment rate at primary and tertiary level). Also, per capita GDP is found to have significant long-run relationship with the educational outcome. 
Table 4 Results of co-integration test between education expenditure and education output

\begin{tabular}{lcc}
\hline Null hypothesis & trace & $J_{\text {max }}$ \\
\hline Education expenditure and adult literacy rate & & \\
$r=0$ & $27.159(0.005)$ & $17.131(0.032)$ \\
$r=1$ & $10.028(0.034)$ & $10.028(0.034)$ \\
Education expenditure and elderly literacy rate & & \\
$r=0$ & $18.105(0.020)$ & $17.358(0.016)$ \\
$r=1$ & $0.747(0.388)$ & $0.747(0.388)$ \\
Education expenditure and youth literacy rate & & \\
$r=0$ & $25.075(0.001)$ & $24.789(0.001)$ \\
$r=1$ & $0.286(0.593)$ & $0.286(0.593)$ \\
Education expenditure and primary net enrolment rate & & $16.497(0.04)$ \\
$r=0$ & $31.686(0.001)$ & $15.189(0.003)$ \\
$r=1$ & $15.189(0.003)$ & \\
Education expenditure and secondary gross enrolment rate & & $4.773(0.770)$ \\
$r=0$ & $4.820(0.828)$ & $0.0472(0.827)$ \\
$r=1$ & $0.0472(0.827)$ & \\
Education expenditure and secondary net enrolment rate & & $5.577(0.668)$ \\
$r=0$ & $5.580(0.745)$ & $0.002(0.960)$ \\
$r=1$ & $0.002(0.960)$ & $18.330(0.020)$ \\
Education expenditure and tertiary gross enrolment rate & & $7.784(0.090)$ \\
$r=0$ & $26.114(0.007)$ & \\
$r=1$ & $7.784(0.090)$ & \\
\hline$p$ a & &
\end{tabular}

$p$ value is in the parentheses

Table 5 Results of co-integration test between per capita GDP, education and healthcare expenditure

\begin{tabular}{lcr}
\hline Null hypothesis & J trace & ${ }^{\prime}$ max \\
\hline $\begin{array}{l}\text { Per capita GDP and per capita education expenditure and per capita GDP and per capita healthcare expendi- } \\
\text { ture } \\
r=0\end{array}$ & $32.852(0.001)$ & $21.707(0.005)$ \\
$r=1$ & $8.884(0.020)$ & $8.884(0.020)$ \\
\hline $\begin{array}{l}\text { p value is in the parentheses, the results of per capita GDP and per capita education expenditure; and of per capita GDP and } \\
\text { per capita healthcare expenditure are exactly similar }\end{array}$
\end{tabular}

Furthermore, the result reveals that government spending on education and healthcare as well as the rate of literacy have positive and significant long-run influence on the growth of economy.

The estimated coefficient of the co-integration regression residual $\mathrm{EC}_{t-1}$ is negative as it should be for most of the variables (Table 6). Nonetheless, the $\mathrm{EC}_{t-1}$ for infant mortality rate and primary net enrolment rate are found to be not significant implying that there is no short-run relationship between government expenditure on healthcare and infant mortality rate as well as between government expenditure on education and primary net enrolment rate. Thus, there is sufficient evidence to show that in the short run, government expenditure on healthcare and education do not have much influence on infant mortality and primary net enrolment. 


\subsubsection{Box 1: Healthcare expenditure and education expenditure}

Healthcare expenditure

Fertility rate

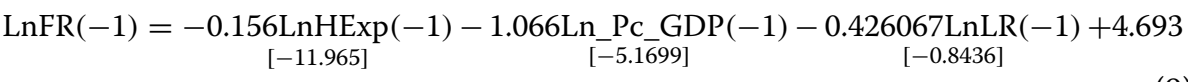

Infant mortality rate

$\operatorname{LnIMR}(-1)=-0.970 \operatorname{LnHExp}(-1)-0.4268 \operatorname{Ln} \_P c \_G D P(-1)-0.01937 \operatorname{LnLR}(-1)+3.533$ [9.9812] [-2.8181] [-0.0733]

Education expenditure

Literacy rate-adult

$$
\operatorname{LnLR}-\mathrm{A}(-1)=0.0449 \operatorname{LnEExp}(-1)-0.138 \operatorname{Ln\_ Pc\_ GDP}(-1)+3.444
$$

Literacy rate-elderly

$$
\operatorname{LnLR}-\mathrm{E}(-1)=\underset{[4.1593]}{0.1582 \operatorname{LnEExp}}(-1)+0.409 \operatorname{Ln} \_\underset{[1.5879]}{P C}(-1)+0.4859
$$

Literacy rate-youth

$$
\operatorname{LnLR}-\mathrm{Y}(-1)=\underset{[3.994]}{0.4484 \operatorname{LnEExp}}(-1)+0.167 \mathrm{Ln} \_\underset{[1.76545]}{\text { Pc_GDP }}(-1)+3.5256
$$

Primary net enrolment rate

$$
\begin{aligned}
& \operatorname{LnSER} \_P N(-1)=0.0263 \operatorname{LnEExp}(-1)+0.025 \operatorname{Ln} \_ \text {Pc_GDP }(-1)+3.842 \\
& \text { [9.7427] [8.0722] }
\end{aligned}
$$

Tertiary gross enrolment rate

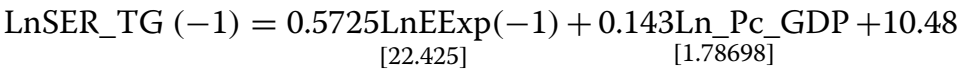

Per capita GDP and expenditure

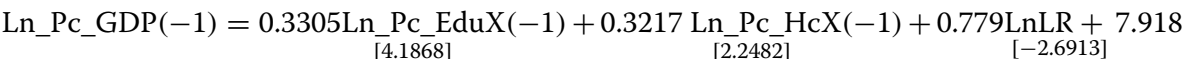

Note: $t$-statistics are in [ ] LnFR $=\log$ of fertility rate, LnHExp $=\log$ of government healthcare expenditure, LnLR = log of literacy rate, LnLR-A, E and Y = log of literacy (Adult, Elderly and Youth), LnSER_PN = log of primary net school enrolment rate, LnSER_TG $=$ log of tertiary school gross enrolment rate, LnPc_GDP $=$ per capita GDP. 
Table 6 Vector error correction models

\begin{tabular}{|c|c|c|c|c|c|}
\hline \multicolumn{6}{|c|}{ Vector error correction model: healthcare expenditure } \\
\hline ECT_1 & -0.3587 & -0.53366 & -0.35205 & & \\
\hline $\begin{array}{l}\text { Healthcare } \\
\text { expend. }\end{array}$ & {$[-3.2460]$} & {$[-4.3981]$} & {$[-2.3215]$} & & \\
\hline Variable & $\begin{array}{l}\text { Fertility rate per } \\
\text { birth }\end{array}$ & $\begin{array}{l}\text { Infant mortality } \\
\text { rate }\end{array}$ & $\begin{array}{l}\text { Under } 5 \text { mortality } \\
\text { rate }\end{array}$ & & \\
\hline \multirow[t]{2}{*}{$\mathrm{ECT} \_1$} & $-2.45,229$ & $5.141,797$ & -7.06507 & & \\
\hline & {$[-2.1999]$} & {$[1.56118]$} & {$[-2.11050]$} & & \\
\hline \multicolumn{6}{|c|}{ Vector error correction model: education expenditure } \\
\hline ECT_1 & -0.25870 & -0.65832 & -0.89956 & -0.13930 & -050442 \\
\hline $\begin{array}{l}\text { Education } \\
\text { expend. }\end{array}$ & {$[-3.04091]$} & {$[-4.15499]$} & {$[-3.76424]$} & {$[-4.09966]$} & {$[-2.63540]$} \\
\hline Variable & $\begin{array}{l}\text { Literacy rate } \\
\text { (adult) }\end{array}$ & $\begin{array}{l}\text { Literacy rate } \\
\text { (elderly) }\end{array}$ & $\begin{array}{l}\text { Literacy rate } \\
\text { (youth) }\end{array}$ & $\begin{array}{l}\text { Primary net } \\
\text { enrolment } \\
\text { rate }\end{array}$ & $\begin{array}{l}\text { Tertiary gross } \\
\text { enrolment } \\
\text { rate }\end{array}$ \\
\hline \multirow[t]{2}{*}{ ECT_1 } & -1.27301 & -0.39567 & -4.58443 & 0.17322 & -0.33121 \\
\hline & {$[-2.01647]$} & {$[-0.72101]$} & {$[-1.58182]$} & {$[0.54551]$} & {$[-1.60418]$} \\
\hline \multicolumn{6}{|c|}{ Vector error correction model: per capita GDP } \\
\hline ECT_1 & -0.053170 & -0.05306 & & & \\
\hline Per capita GDP & {$[-3.52063]$} & {$[-3.53603]$} & & & \\
\hline Variable & $\begin{array}{l}\text { Healthcare } \\
\text { expenditure }\end{array}$ & $\begin{array}{l}\text { Education } \\
\text { expenditure }\end{array}$ & & & \\
\hline \multirow[t]{2}{*}{ ECT_1 } & -0.01953 & 0.15589 & & & \\
\hline & {$[-0.28580]$} & [0.25424] & & & \\
\hline
\end{tabular}

$t$-statistics are in the parentheses

\section{Conclusion and recommendation}

In this paper, we tried to examine if there is a long-run relationship between government spending on healthcare and mortality rate, life-expectancy. Also, we examined whether there is any long-run relationship between government spending on education and literacy rate, school enrolment rate and then examined the short-run relationship between government spending on healthcare and education and per capita GDP in Namibia using a dataset for the period 1980 and 2015.

The resultant outcome is a mix. Here, analysis reveals long-run relationship between government spending on healthcare and fertility rate, infant mortality rate and under- 5 mortality rate. However, no co-integration is observed between government spending on healthcare and life-expectancy and adult mortality rate. This implies that there is no long-run relationship government spending on healthcare and life-expectancy at birth and adult mortality rate so far. This could be because soon after the country's independence, the issues of HIV/AIDS and other communicative diseases like TB and Malaria arose (UN-AIDS 2006; Gueye et al. 2014; Kharsany and Karim 2016). Therefore, the country was still struggling with capacity during the first years of independence (Iipinge et al. 2006).

The study revealed a long-run relationship between government spending on education and literacy rate at all level (youth, adult and elderly). Moreover, no co-integration between government spending on education and gross enrolment rate at primary and secondary level is observed. This is because primary enrolment in the country is already high as seen earlier. Thus, any extra-spending on the education would not increase it 
further. Nonetheless, the analysis shows a long-run relationship between government spending on education and net primary enrolment rate as well as gross tertiary enrolment rate. The results further indicate that there is a long-run relationship between government spending on education and healthcare and per capita gross domestic product (GDP) for the study period.

This implies that a pragmatic and objective led expansionary government expenditure policy may be adopted to realise a better health and educational outcome as well as a faster economic growth, not only in Namibia but also in any developing country with similar issue as was earlier referred that investments on education and healthcare do not always deliver the required output in developing nations (Gray et al. 2007). This finding has a clear implication for the debate on sustainability of public finances. It is often claimed that rising government spending would be a key to ensure the sustainable economic development over the long run as it is proposed by Keynes (1936). Even though the evidences from the estimations support the Keynes' theory in some aspects, the findings suggest that there is no strong long-run relation between government spending on social sector activities and some development indicators (like, adult mortality rate, lifeexpectancy and primary enrolment rate) in Namibia. This is due to the fact that still the economy is in reconstruction phase after the independence and some results on health outcome and some educational outcome started showing results only after 2000 . There is an apparent inefficiency in the use of growing expenditure due to sudden shortage of required manpower immediately after the independence. Thus, resources invested in the sector were not properly directed. The findings are therefore in favour of the Namibian government to promote efficiency on its expenditure to guarantee overall development in the long run.

The following recommendations can thus be drawn. Structural reforms on education and healthcare sector are required to ensure that skills' development is enhanced in areas that are critical to the economic development. Hence, the education system should be skill-demand oriented to ensure that there is no mismatch between the demand for skill and supply in the economy. Whilst the healthcare sector needs to be strengthened to warrant a healthy nation which is ready to learn new skills and capable to work and enhance productivity. Government funds must be channelled in rightful projects at the right time to meet the country's demand rather than spending on enormous projects that would not translate into any meaningful development of the economy. The public investment should be more focused on education and healthcare infrastructure as well as on skill development rather than spending more in education and healthcare personnel and other consumables, which is observed from the available data (Govt. of Namibia 2013).

\section{Acknowledgements}

Not applicable.

Authors' contributions

Both authors have contributed equally to the work. Both authors read and approved the final manuscript.

Funding

The author(s) declare(s) that they have not received any funding for this research work. 
php and Ministry of Higher Education, Training and Innovation: http://www.mheti.gov.na/key-information/. Furthermore, the datasets used and/or analysed during the current study are available from the corresponding author on reasonable request.

\section{Competing interests}

The authors declare that they have no competing interests.

\section{Author details}

${ }^{1}$ Department of Economics and Managemen, University of Namibia Rundu, 44001, Kavango East, Rundu, Namibia.

2 Department of Economics, North-Eastern Hill University Shillong, Shillong, Meghalaya 793022, India.

Received: 13 February 2019 Revised: 8 February 2020 Accepted: 15 February 2020

Published online: 28 February 2020

\section{References}

Afzal M, Farook MS, Ahmed HK, Begum I, Quddus MA (2010) Relationship between School education and economic growth in Pakistan: ARDL bounds testing approach to cointegration. Pak Eco Soc Rev. 48(1):39-60 Agenor PR (2008) Fiscal policy and endogenous growth with public infrastructure. Oxf Eco Papers 60:57-87 Asteriou D, Hall S (2011) Applied econometrics, 2nd edn. Palgrave Macmillan, New York

Baldacci E, Cui Q, Clements BJ, Gupta S (2004) Social spending, human capital, and growth in developing countries: implications for achieving the MDGs. IMF Working Papers 04(217):1

Barro RJ (1996) Determinants of economic growth: a cross-country empirical study. NBER Working Paper No. 5698

Barro R (2013) Health and economic growth. Ann Eco Fin. 14(2):329-366

Becker G (1962) Investment in human capital: a theoretical analysis. J Pol Econ 70:9-49 (5, part 2)

Becker G (1964a) Human capital: a theoretical and empirical analysis, with special reference to education. University of Chicago Press, Chicago

Becker G (1964b) Human capital. Columbia University Press, New York

Benos N, Zotou S (2014) Education and economic growth: a meta-regression analysis. World Dev. 64:669-689

Bloom DE, Canning D (2000) The health and wealth of nations. Science 287:1207-1209

Bloom DE, Canning D, Sevilla J (2001) The effect of health on economic growth: theory and evidence. AmbriNBER Working Paper No. 8587

Bloom DE, Canning D, Sevilla J (2004) The effect of health on economic growth: a production function approach. World Dev 32(1):1-13

Bowles S (1967) The efficient allocation of resources in education. Quart J Eco. 81(2):189-219

Brockwell PJ, Davis RA (1996) Introduction to time series and forecasting. Springer, New York

Commander MJ, Sashidharan SP, Odell SM, Surtees PG (1997) Access to mental health care in an inner-city health district I: pathways into and within specialist psychiatric services. Br J Psych. 170:312-316

Denison E (1962) Education, economic growth, and gaps in information. J Pol Econ 70(5):124-128 (part 2)

Dickey DA, Fuller W (1979) Distribution of the estimators for autoregressive time series with a unit root. J Am Stat Ass. 74(366):427-431

Eagle RF, Yoo B (1987) Forecasting and testing in cointegrated systems. J Econ 35(2):143-159

Engle RF, Granger CWJ (1987) Cointegration and error correction: representation and testing. Econ. 55:251-276

Goldin C (2016) Human capital. In: Diebolt C, Haupert M (eds) Handbook of cliometrics. Heidelberg, Berlin

Govt. of Namibia, Ministry of Finance (2013) Medium term expenditure framework. Own publisher, Windhoek Granger CJW (1980) Testing for causality. J Econ Dyn Control 2:329-352

Granger CWJ (1981) Some properties of time sires data and their use in econometric model specification. J Econ 16(1):121-130

Gray C (2007) Fiscal policy and economic growth in Europe and Central Asia: an overview. In: Gray C, Lane T, Varoudakis A (eds) Fiscal policy and economic growth, lessons for eastern Europe and Central Asia. World Bank Publications, Washington DC

Gray C, Lane T, Varoudakis A (eds) (2007) Fiscal policy and economic growth, lessons for eastern Europe and central Asia. World Bank, Washington DC

Green F, Ashton D, James D, Sung J (1999) The role of the state in skill formation: evidence from the Republic of Korea, Singapore, and Taiwan. Oxf Rev Eco Pol. 15(1):82-96

Grossman M (1972) On the concept of health capital and the demand for health. J Pol Econ. 80:223-255

Gueye SC, Gerigk M, Newby G et al (2014) Namibia's path toward malaria elimination: a case study of malaria strategies and costs along the northern border. BMC Public Health. https://doi.org/10.1186/1471-2458-14-1190

Gupta S, Verhoeven M, Tiongson E (2002) The effectiveness of government spending on education and health care in developing and transition economies. Euro J Pol Econ. 18(4):717-737

Hanushek EA (2013) Economic growth in developing countries: the role of human capital. Eco Edu Rev. 37:204-212 lipinge SN, Hofnie K, van der Westhuizen L and Pendukeni M (2006) Perceptions of health workers about conditions of service: a Namibian case study. Regional Network for Equity in Health in Southern Africa (EQUINET), EQUINET Discussion Paper 35. http://www.albacharia.ma/xmlui/bitstream/handle/123456789/31905/DIS35HRiipinge.pdf International Monetary Fund (2014). IMF Country Report No. 14/41. International Monetary Fund. Washington Isaksson A (2007) Determinants of total factor productivity: a literature review. United Nations Industrial Development Organisation, Vienna

Johansen S (1988) Statistical analysis of cointegrating vectors. J Eco Dyn Cont. 12(2-3):231-254

Johansen S (1991) Estimating and testing cointegration vectors in Gaussian vector autoregressive models. Econ. 59:1551-1580 
Kalimbo HN (2015) Namibia competitiveness ranking: Are we addressing the real issue? Policy brief 04/2015. National Planning Commission, Windhoek

Keynes JM (1936) The general theory of employment, interest and money. Cambridge University Press, New York Kharsany ABM, Karim QA (2016) HIV infection and AIDS in sub-Saharan Africa: current status, challenges and opportunities. Open AIDS J. 10:34-48

Liew KS (2000) The performance of AICC as lag length determination criterion in the selection of ARMA time series models. Unpublished Thesis, Department of Mathematics, Universiti Putra Malaysia

Lin TC (2003) Education, technical progress, and economic growth: the case of Taiwan. Eco Edu Rev. 22:213-220

Liu CL, Hsu C, Younis M (2008) The association between government expenditure and economic growth: the granger causality test of the USA data. J Pub Budg Acc Fin Mangt 20(4):439-452

Loizides J, Vamvoukas G (2005) Government expenditure and economic growth: evidence from trivariate causality testing. J Appl Eco. 8(1):125-152

Low A, Ithindi T, Low A (2003) A Step too far? Making health equity interventions in Namibia more sufficient. Int J Equity Health. 2(1):5-16

Maitra B, Mukhopadhyay CK (2012) Public spending on education, health care and economic growth in selected Countries of Asia and the Pacific. Asia-Pac Dev J. 19(2):19-48

McMahon WW (1997) Recent advances in measuring the social and individual benefits of education. Int J Educ Res 27(6):449-531

Mekdad Y, Dahmani A, Louaj M (2014) Public spending on education and economic growth in Algeria: causality test. Int J Bus Manag. 2(3):55-70

Mincer J (1984) Human capital and economic growth. Eco Edu Rev. 3(3):195-205

Mushkin SJ (1962) Health as an investment. J Pol Econ. 70(5):129-157

Ogundari K, Abdulai A (2014) Determinants of education and healthcare spending in Nigeria: evidence from survey data. Afr Dev Rev. 26(1):1-14

Ogundari K, Awokuse T (2018) Human capital contribution to economic growth in Sub-Saharan Africa: does health status matter more than education? Eco Anal Pol. 58:131-140

Phillips PCB (1986) Understanding spurious regression in econometrics. J Econ 33:311-340

Phillips PCB (1987) Time series regression with unit root. Econ. 55:277-301

Phillips PCB, Ouliaris S (1990) Asymptotic properties of residual based cointegration. Econ. 58:165-193

Schultz TW (1961) Investment in human capital. Am Eco Rev. 51:1-17

Sen A (1999) Development as freedom. Oxford University Press, Oxford

Sims CA (1980) Macroeconomics and reality. Econometrica 48:1-48

Stock JH, Watson MW (1988) Testing for common trends. J Am Stat Ass. 83:1035-1107

Strauss J, Thomas D (1998) Health, nutrition, and economic development. J Eco Lit. 36(2):766-817

Suri T, Boozer MA, Ranis G (2011) Paths to success: the relationship between human development and economic growth. World Dev 39(4):506-522

Tamang P (2011) The impact of education expenditure on India's economic growth. Jof Int Aca Res. 11(3):14-20

UN-AIDS (2006) Report on the Global AIDS epidemic. United Nations, Geneva

Wahab M (2004) Economic growth and government expenditure: evidence from a new test specification. App Eco. $36: 2125-2135$

Wang K (2011) Health care and economic growth: quantile panel-type analysis. Eco Mod. 28(4):1536-1549

Wilson MR (1995) Medical care expenditure and GDP growth in OECD nations. Soc Sci Med 14:25-32

Zaaruka, B, Biwa B, Kalenga P (2001) Public expenditure management in Namibia health and education sectors-preliminary analysis. BON Working Paper No.1/02

\section{Publisher's Note}

Springer Nature remains neutral with regard to jurisdictional claims in published maps and institutional affiliations.

\section{Submit your manuscript to a SpringerOpen ${ }^{\circ}$ journal and benefit from:}

- Convenient online submission

- Rigorous peer review

- Open access: articles freely available online

- High visibility within the field

- Retaining the copyright to your article

Submit your next manuscript at $\boldsymbol{\nabla}$ springeropen.com 